\title{
Esophagectomy complications and mortality in esophageal cancer patients, a comparison between trans- thoracic and trans-hiatal methods
}

\author{
Mehdi Aramesh1, Mohammad Shirkhoda1, Maryam Hadji', Parisa Seifi, Ramesh Omranipour ${ }^{1}$, \\ Mohammad Ali Mohagheghi ${ }^{1}$, Mehdi Aghili ${ }^{1}$, Amirmohsen Jalaeefar ${ }^{2}$, Nahid Karkhaneh Yousefi ${ }^{1}$, Kazem Zendedel ${ }^{1}$
}

\begin{abstract}
Introduction: Esophageal cancer is the sixth cause of cancer related deaths worldwide. Esophagectomy is the standard treatment for non-metastatic esophageal cancer, but is associated with high mortality and morbidity rates. We evaluated the mortality and complications following esophagectomy, and factors affecting it (including the surgical approach).

Methods: This retrospective study was performed from 2006 to 2012; the data were collected from medical files of esophageal cancer patients who underwent surgical procedures at Iran's cancer institute and analyzed.

Results: A total of 254 operated esophageal cancer patients entered this study. Patients included 105 males and 149 females, with a mean age of 65.70. Of all the operated patients, 121 (47.64\%) underwent the trans-hiatal and 121 (47.64\%) the transthoracic esophagectomy method, also 12 patients were operated by other surgical methods. Post-operative complications occurred in 61 patients (24.02\%). Respiratory complications (20.08\%) -including Adults Respiratory Distress Syndrome (9.45 \%), pneumonia (6.30\%) and ventilator dependency (4.33\%) - were the most common complications. Other major complications were anastomosis leakage and fistula (6.30\%), atrial fibrillation (6.30 \%), chylothorax (3.15\%), bleeding requiring reoperation (1.97\%) and pulmonary embolism (1.97\%). In-hospital mortality rate was $5.12 \%$. Pneumonia, ICU admission and intubation time were significantly higher in transthoracic than trans-hiatal method but mortality was not significantly different. ARDS, ventilator dependency and history of cardio-pulmonary disease were prognostic for in-hospital mortality.

Conclusion: Although esophagectomy is a complex surgery and associated with multiple complications, in case of proper patient selection and experienced surgeons, both the transthoracic and trans-hiatal esophagectomy methods have appropriate results.
\end{abstract}

Keywords: esophagectomy, complication, cancer, transthoracic, trans-hiatal

\section{INTRODUCTION}

Esophageal cancer is the sixth cause of cancer related deaths worldwide(1), with 456,000 new cases and 400000 mortalities in 2012 (2). The high risk region for esophageal cancer is known as the "esophageal cancer belt ", starting from northern Iran through the central Asian countries to north-central China. Since Iran is also located on this cancer belt, esophageal cancer has high prevalence in this country. Most (90\%) of esophageal cancer cases in the regions located on this belt are squamous cell carcinomas, whereas this histological type is much less in the United States (26\%) (2).

Two main histological types of esophageal cancer are: 1 . squamous cell carcinoma (the most common type), usually occurring in the proximal two thirds of the esophagus, and 2. Adenocarcinoma, which mostly occurs in the lower third of the esophagus.

Treatment method of esophageal cancer depends on tumor site and stage. These methods include: esophagectomy, neo-adjuvant therapy followed by surgery, definitive chemo-radiation and palliative surgery for metastatic patients. In tumors invading muscularis properia, esophagectomy in combination with chemo-radiation therapy as neo-adjuvant, remains the optimal management for patients who are medically fit for esophageal cancer surgery.

\footnotetext{
1 Cancer Research Center, Cancer Institute of Iran, Tehran University of Medical

Sciences, Tehran, Iran.

2 Department of Surgery, Cancer Institute of Iran, Tehran University of Medical

Sciences, Tehran, Iran.
}

Received: 27 Mar 2018, Accepted: 5 Jun 2018

Correspondence: Mohammad Shirkhoda

Cancer Research Center, Cancer Institute of Iran, Tehran University of Medical Sciences.

E-mail:mshirkhoda@sina.tums.ac.ir

(c) 2019 by the authors; licensee Modestum Ltd., UK. This article is an open access article distributed under the terms and conditions of the Creative Commons Attribution License (http://creativecommons.org/licenses/by/4.0/). 
In 1940, Oschner and DeBakey reviewed the literature on esophageal resections, and reported about $72 \%$ mortality after esophagectomy (3). Many improvements have been made in esophageal cancer treatment since then, but post esophagectomy mortality and morbidity rates are still considerable. Esophagectomy usually involves the abdomen, thorax and neck, making it a greatly traumatic and technically complex surgery, and therefore having a high rate of complications and mortality (4).

According to multiple analyses performed to identify post-surgical complications and risk factors of esophagectomy, the most common complications include: pulmonary complications (such as Adults Respiratory Distress Syndrome (ARDS), pleural effusion, atelectasis, ventilator dependency and pneumonia), cardiac complications (cardiac arrhythmia and myocardial infarction), anastomotic leakage \& fistula, thrombo-embolic events, chylothorax, intra and postoperative bleeding, wound infection and acid-base disorder (5-9). Complications may vary in different surgical techniques.

Regarding esophageal cancer being endemic in Iran, and previous studies conducted in the Cancer Institute of Iran, that showed a relatively high early mortality rate of esophagectomy (10), we decided to evaluate in-hospital complications and mortality of esophagectomy and factors affecting it, including patient's characteristics and the surgical approach.

\section{METHODS}

Iran's Cancer Institute is the only hospital specialized for cancer treatment in the country, and it is one of the most important referral centers for esophageal cancer in Iran.

In our center, spirometry and echocardiography is done for all patients who need esophagectomy, and also consultation with a cardiologist and pulmonary specialist is done for patients aged over 40 years. High risk patients (according to the cardiac and pulmonary consultation), were referred for definite chemo-radiotherapy, and the rest underwent surgery. The operated patients may have a history of cardiopulmonary disease (coronary angioplasty or bypass), but have a moderate risk for surgery at present.

In this center, esophagectomy is mainly done by two methods: Three-hole Trans-Thoracic Esophagectomy (TTE) and Trans-Hiatal Esophagectomy (THE).

In the TTE method, at first a right thoracotomy is performed, the thoracic esophagus and the lymph nodes are dissected, followed by closure of chest incision; through the abdominal incision, gastric pull up or colon interposition is done in supine position and reconstruction is performed by neck anastomosis.

In the THE method, after laparotomy and gastro lysis, esophageal dissection is done from hiatus to the neck, esophagus is explored in the neck and then anastomosis is done between cervical esophagus and stomach, so there is no thoracic incision.

This retrospective study was performed during the years 2006 to 2012; all the medical files of esophageal cancer patients who underwent surgical procedures at the department of surgery of Iran's Cancer Institute were collected. Eligible patients were defined as esophageal cancer patients who underwent curative surgery. Patients with distant metastasis were excluded, except one patient who had a minor limited metastasis that was resected.

Esophageal cancer staging was done based on standardized workup, including endoscopy with biopsy, endoscopic ultrasound (EUS) and computed tomography scan of thorax, abdomen and pelvis, according to the sixth edition of AJCC guideline for staging.

The collected data included: patient's demographic data (age, gender, tumor stage and location ), patient's preoperative condition (history of cardio-pulmonary disease and general health), pathological findings (tumor site, histology, invasion of adjacent organs, and lymph node metastasis), surgical technique, intra-operative blood transfusion (at least two units of packed blood cells), hospital mortality and post-operative complications (including pneumonia, ARDS, ventilator dependency - ventilator support beyond $48 \mathrm{~h}$ - , pulmonary embolism, chylothorax, atrial fibrillation, anastomotic leakage and fistula formation). Complications were defined according to the "international consensus on standardization of data collection for complications associated with esophagectomy"(5) .

In the current study we evaluated:

1. the association between complications and hospital mortality, and

2. the association of complications and hospital mortality with the patient's characteristics and surgery method.

This study was approved by the ethics committee of Tehran University of Medical Sciences. 


\section{Statistical Analysis}

Statistical analysis was performed using the STATA software version 11 (State Corp., College station, TX), and all considered $p$-values were two sided. In order to signify data distribution, we conducted the Shapiro-Wilk test and considered normal distribution based on $p$-value $\geq 0.05$. Using unconditional logistic regression, we estimated odds ratio (OR) and $95 \%$ confidence intervals to evaluate the association between esophageal cancer complications and potential risk factors. Fully adjusted models included any variable which showed p-value more than 0.2 in univariate analysis. In order to choose the best model, we fitted the last multivariate model based on the likelihood ratio test and estimated the area under the curve, that was between 0.70-0.80. Also, we evaluated the co-linearity between risk factors based on their variance inflation factor (VIF), and selected all variables with a variance inflation factor (VIF) less than 10. Furthermore, in order to assess the co-linearity, we tested the association between each variable based on Chi2, independent t-test, and ANOVA.

\section{RESULTS}

\section{Demographic Data}

A total of 254 operated esophageal cancer patients entered the present study. Patients included 105 males (41.34\%), and 149 females $(58.66 \%)$, with a mean age $( \pm S D)$ of $65.70( \pm 12.80)$. Cases of SCC and adenocarcinoma were $96.06 \%$ and $3.94 \%$ respectively. Of all the operated patients, $121(47.64 \%)$ underwent the trans-hiatal and $121(47.64 \%)$ the transthoracic esophagectomy method, also 12 patients were operated by other surgical methods (Ivor Lewis, Left thoracotomy...etc.). The clinico-pathological characteristics of all 254 patients have been demonstrated in Table 1. According to this table, $44.49 \%$ of patients were categorized as stage II, and $51.97 \%$ as stage III. In $39.76 \%$ and $49.21 \%$ of patients the middle and lower third of esophagus were involved respectively. Intra-operative blood transfusion (at least 2 units of packed cell) was required in 27(10.63\%) patients. 
Table 1: Characteristics of patients who underwent esophagectomy between the years 2006 to 2012 in Cancer Institute of I.R Iran, Tehran, Iran

\begin{tabular}{|c|c|}
\hline Variable & Number (\%) \\
\hline \multicolumn{2}{|l|}{ Age group } \\
\hline$<50$ & $67(26.38)$ \\
\hline $50-60$ & $88(34.65)$ \\
\hline $60-70$ & $67(26.37)$ \\
\hline$>70$ & $28(11.02)$ \\
\hline Missing & $4(1.57)$ \\
\hline \multicolumn{2}{|l|}{ Gender } \\
\hline Female & $149(58.66)$ \\
\hline Male & $105(41.34)$ \\
\hline \multicolumn{2}{|l|}{ Tumor Stage } \\
\hline 1 & $6(2.36)$ \\
\hline II & $113(44.49)$ \\
\hline III & $132(51.97)$ \\
\hline IV & $1(0.39)$ \\
\hline Unknown & $2(0.79)$ \\
\hline \multicolumn{2}{|l|}{ Tumor Location } \\
\hline Upper third of Esophagus & $8(3.15)$ \\
\hline Middle third of Esophagus & $101(39.76)$ \\
\hline Lower third of Esophagus & $125(49.21)$ \\
\hline Unknown & $20(7.87)$ \\
\hline \multicolumn{2}{|l|}{ History of cardiopulmonary Disease } \\
\hline No & 198(77.95) \\
\hline Yes & $56(22.05)$ \\
\hline \multicolumn{2}{|l|}{ Intraoperative Blood Transfusion* } \\
\hline No & $227(89.37)$ \\
\hline Yes & $27(10.63)$ \\
\hline \multicolumn{2}{|l|}{ General health** } \\
\hline Inappropriate & $27(10.63)$ \\
\hline Appropriate & $227(89.37)$ \\
\hline \multicolumn{2}{|l|}{ Surgical approach } \\
\hline Trans-hiatal esophagectomy & $121(47.64)$ \\
\hline Trans-thoracic(Three-hole) esophagectomy & $121(47.64)$ \\
\hline Other*** method & $12(4.72)$ \\
\hline \multicolumn{2}{|l|}{ Neo-adjuvant treatment } \\
\hline No & $214(84.25()$ \\
\hline Yes & $40(15.75)$ \\
\hline
\end{tabular}

*at least 2 units of packed blood cells

**General condition: the patient's appearance regarding being healthy, cachexia, etc. that was evaluated based on the notes of the nurse at the time of admission to the ward

${ }^{* * *}$ Other means: Ivor Lewis, Left thoracotomy, etc.

\section{Complications and Mortality Rates}

The overall in-hospital mortality was 13 (5.12 \%) and post-operative complications were 61 (24.02\%). Some patients experienced more than one complication. However, the major post-operative complications included: ARDS 24 (9.45\%), pneumonia 16 (6.30\%), anastomotic leakage and fistula formation 16 (6.30\%), ventilator dependency 11 (4.33\%), chylothorax 8 (3.15\%), pulmonary embolism 5 (1.97\%) and bleeding requiring re-operation 5 (1.97\%) (Table 2). 
Table 2: Post-operative complications and hospital mortality in patients who underwent esophagectomy between the years 2006 to 2012 in Cancer Institute of I.R Iran, Tehran, Iran

\begin{tabular}{|c|c|}
\hline Complication & Number (\%) \\
\hline No & $193(75.98)$ \\
\hline Yes & $61(24.02)$ \\
\hline \multicolumn{2}{|l|}{ pneumonia } \\
\hline No & $238(93.70)$ \\
\hline Yes & $16(6.30)$ \\
\hline \multicolumn{2}{|l|}{ ARDS* } \\
\hline No & $230(90.55)$ \\
\hline Yes & $24(9.45$ \\
\hline \multicolumn{2}{|c|}{ Pulmonary embolism } \\
\hline No & $249(98.03)$ \\
\hline Yes & $5(1.97)$ \\
\hline \multicolumn{2}{|c|}{ ventilator dependency (ventilation support beyond 48 hours) } \\
\hline No & $243(95.67)$ \\
\hline Yes & $11(4.33)$ \\
\hline \multicolumn{2}{|l|}{ Chylothorax } \\
\hline No & $246(96.85)$ \\
\hline Yes & $8(3.15)$ \\
\hline \multicolumn{2}{|c|}{ Anastomotic leakage $\&$ fistula } \\
\hline No & $238(93.70)$ \\
\hline Yes & $16(6.30)$ \\
\hline \multicolumn{2}{|c|}{ Bleeding requiring re-operation } \\
\hline No & $249(98.03)$ \\
\hline Yes & $5(1.97)$ \\
\hline \multicolumn{2}{|l|}{ Atrial fibrillation } \\
\hline No & $238(93.70)$ \\
\hline Yes & $16(6.30)$ \\
\hline \multicolumn{2}{|c|}{ Recurrent laryngeal nerve paralysis } \\
\hline No & $253(99.61)$ \\
\hline Yes & $1(0.39)$ \\
\hline \multicolumn{2}{|l|}{ Hospital mortality } \\
\hline No & $241(94.88)$ \\
\hline Yes & $13(5.12)$ \\
\hline
\end{tabular}

*Adults Respiratory Distress Syndrome

\section{Risk Factors}

In the multi-variate logistic model, the association of complications and mortality with other parameters was evaluated (Table 3).

Our findings showed that in patients with history of cardio-pulmonary disease, the risk of mortality and complications are significantly higher. Also, risk of complication increases with age in the 60-70 year age group. Complications were significantly higher in patients who received intra-operative blood transfusion. There was no difference regarding complications and mortality in the group who received neo-adjuvant treatment compared to the group who didn't. Furthermore, risk of complications and mortality was not related to tumor stage and location. 
Table 3: Adjusted odds ratios (OR) and corresponding 95\% confidence interval (CI) for association between complications, hospital mortality and patient characteristics, among patients who underwent esophagectomy from 2006 to 2012 in Cancer Institute of I.R Iran, Tehran, Iran

\begin{tabular}{|c|c|c|c|c|c|c|}
\hline \multirow{2}{*}{ Variables } & \multirow{2}{*}{\begin{tabular}{c|} 
Total complication \\
(Yes (\%)/No(\%))
\end{tabular}} & \multicolumn{5}{|c|}{ Hospital Mortality } \\
\hline & & Adjusted OR (95\% Cl) & P-Value & $(\mathrm{Yes}(\%) / \mathrm{No}(\%))$ & Adjusted OR (95\% Cl) & P-Value \\
\hline \multicolumn{7}{|l|}{ Age group } \\
\hline$<50$ & $11(16.42) / 56(83.58)$ & Reference & ............. & $0(0.00) / 67(100.00)$ & …................. & ............. \\
\hline $50-60$ & $20(22.73) / 68(77.27)$ & $2.16(0.85,5.50)$ & $>0.05$ & $6(6.82) / 82(93.18)$ & ……................ & ............ \\
\hline $60-70$ & $22(32.84) / 45(67.16)$ & $3.84(1.50,9.90)$ & $<0.05$ & $6(8.96) / 61(91.04)$ & ……….......... & ............. \\
\hline$>70$ & $7(25.00) / 21(75.00)$ & $2.94(0.90,9.96)$ & $>0.05$ & $1(3.57) / 27(96.43)$ & …................. & ............. \\
\hline Missing & $1(25) / 3(75)$ & ....................... & ............. & $0(0.00) / 4(100.00)$ & ....................... & ............ \\
\hline \multicolumn{7}{|l|}{ Gender } \\
\hline Female & $36(24.16) / 113(75.84)$ & Reference & & $10(6.71) / 139(93.29)$ & Reference & ............ \\
\hline Male & $25(23.81) / 80(76.19)$ & $1.03(0.53,2.00)$ & $>0.05$ & $3(2.86) / 102(97.14)$ & $0.53(0.13,2.20)$ & $>0.05$ \\
\hline \multicolumn{7}{|l|}{ Tumor stage } \\
\hline 1 & $1(16.67) / 5(83.33)$ & $0.64(0.06,6.60)$ & $>0.05$ & $0(0.00) / 6(100.00)$ & ........................ & ........... \\
\hline II & $25(22.12) / 88(77.88)$ & Reference & ............ & $7(6.19) / 106$ (93.81) & Reference & ............ \\
\hline III & 35 (26.52) / 97 (73.48) & $1.70(0.90,3.25)$ & $>0.05$ & $6(4.55) / 126$ (95.45) & $0.90(0.25,3.03)$ & $>0.05$ \\
\hline IV & $0(0.00) / 1(10.00)$ & .................... & $\ldots \ldots \ldots . .$. & $0(0.00) / 1(100.00)$ & .................... & ........... \\
\hline Unknown & $0(0.00) / 2(100.00)$ & …..................... & $\ldots \ldots \ldots . . .$. & $0(0.00) / 2(100.00)$ & ….................... & ............ \\
\hline \multicolumn{7}{|l|}{ Tumor location } \\
\hline Upper third of esophagus & $3(37.50) / 5(62.50)$ & $2.96(0.60,15.07)$ & $>0.05$ & $0(0.00) / 8(100.00)$ & ……............... & ............ \\
\hline Middle third of esophagus & $27(26.73) / 74(73.27)$ & Reference & $\ldots \ldots \ldots . .$. & $5(4.95) / 96(95.05))$ & Reference & ........... \\
\hline Lower third of esophagus & $24(19.20) / 101(80.80)$ & $0.70(0.33,8.50)$ & $>0.05$ & $7(5.60) / 118(94.40)$ & $1.26(0.34,4.70)$ & $>0.05$ \\
\hline Unknown & $7(35.00) / 13(65.00)$ & $2.62(0.82,8.45)$ & $>0.05$ & $1(5.00) / 19(95.00)$ & $1.50(0.12,16.82)$ & $>0.05$ \\
\hline \multicolumn{7}{|l|}{$\begin{array}{l}\text { History of cardio-pulmonary } \\
\text { disease }\end{array}$} \\
\hline No & $41(20.71) / 157(79.29)$ & Reference & $\ldots \ldots \ldots . .$. & $5(2.53) / 193(97.47)$ & Reference & .............. \\
\hline Yes & $20(35.71) / 36(64.29)$ & $2.45(1.17,5.12)$ & $<0.05$ & $8(14.29) / 48(85.71)$ & $5.02(1.44,17.53)$ & $<0.05$ \\
\hline \multicolumn{7}{|l|}{$\begin{array}{c}\text { Intra-operative blood } \\
\text { transfusion }\end{array}$} \\
\hline No & $50(22.03) / 177(77.97)$ & Reference & ............ & $10(4.41) / 217(95.59)$ & Reference & ............ \\
\hline Yes & $11(40.74) / 16(59.26)$ & $3.32(1.24,8.88)$ & $<0.05$ & $3(11.11) / 24(88.89)$ & $2.40(0.50,11.40)$ & $>0.05$ \\
\hline \multicolumn{7}{|l|}{ General health } \\
\hline Appropriate & $55(90.16) / 172(89.12)$ & Reference & ............ & $12(5.29) / 215(94.71)$ & Reference & ............ \\
\hline Inappropriate & $6(9.84) / 21(10.88)$ & $1.00(0.35,2.84)$ & $>0.05$ & $1(3.70) / 26(96.30)$ & $0.62(0.07,5.63)$ & $>0.05$ \\
\hline \multicolumn{7}{|l|}{ Surgical approach } \\
\hline Trans-hiatal & $21(17.36) / 100(82.64)$ & Reference & ............. & $5(4.13) / 116(95.87)$ & Reference & ................ \\
\hline Transthoracic & $37(30.58) / 84(69.42)$ & $1.84(0.92,3.70)$ & $>0.05$ & $7(5.79) / 114(94.21)$ & $1.40(0.40,5.23)$ & $>0.05$ \\
\hline Other & $3(25.00) / 9(75.00)$ & $0.72(0.13,4.00)$ & $>0.05$ & $1(8.33) / 11(91.66)$ & $1.23(0.08,18.90)$ & $>0.05$ \\
\hline \multicolumn{7}{|l|}{ Neo-adjuvant treatment } \\
\hline No & $50(23.36) / 164(76.64)$ & Reference & $\ldots \ldots \ldots \ldots$ & $9(4.21) / 205(95.79)$ & Reference & .............. \\
\hline Yes & $11(27.50) / 29(72.50)$ & $1.06(0.43,2.60)$ & $>0.05$ & $4(10.00) / 36(90.00)$ & $1.71(0.40,7.20)$ & $>0.05$ \\
\hline
\end{tabular}

\section{Surgical Approach}

In comparison of the TTE and THE methods, it was observed that risk of pneumonia was significantly higher in the TTE method. Although there was no significant difference between the two groups regarding mortality, ARDS, ventilator dependency, and anastomosis leakage (Table 4). 
Table 4: Comparison of complications in Trans hiatal and Transthoracic surgical methods among esophageal cancer patients in Cancer Institute of I.R Iran during the years 2006 to 2012, Tehran, Iran

\begin{tabular}{|c|c|c|c|c|}
\hline \multirow[t]{2}{*}{ Variable } & \multicolumn{2}{|c|}{ Surgical approach } & \multirow[b]{2}{*}{ Adjusted OR (95\% Cl) } & \multirow[b]{2}{*}{ P-Value } \\
\hline & Trans-hiatal N (\%) & Trans-thoracic N (\%) & & \\
\hline \multicolumn{5}{|c|}{ Total complication } \\
\hline No & $100(51.81)$ & $84(43.52)$ & Reference & ................. \\
\hline Yes & $21(34.43)$ & $37(60.66)$ & $0.60(0.11,3.03)$ & $>0.05$ \\
\hline \multicolumn{5}{|l|}{ Pneumonia } \\
\hline No & $118(49.79)$ & 109 (45.99) & Reference & ................. \\
\hline Yes & $3(18.75)$ & $12(75.00)$ & $7.62(1.10,52.64)$ & $<0.05$ \\
\hline \multicolumn{5}{|l|}{ ARDS* } \\
\hline No & $114(49.78)$ & $105(45.85)$ & Reference & .................. \\
\hline Yes & $7(29.17)$ & $16(66.67)$ & $3.70(0.70,19.03)$ & $>0.05$ \\
\hline \multicolumn{5}{|c|}{ Pulmonary embolism } \\
\hline No & $119(47.98)$ & $118(47.58)$ & Reference & .................. \\
\hline Yes & $2(40.00)$ & $3(60.00)$ & $0.64(0.06,7.06)$ & $>0.05$ \\
\hline \multicolumn{5}{|c|}{ Ventilator dependency } \\
\hline No & $117(48.35))$ & $115(47.52)$ & Reference & ................. \\
\hline Yes & $4(36.36)$ & $6(54.55)$ & $0.28(0.03,2.32)$ & $>0.05$ \\
\hline \multicolumn{5}{|c|}{ Chylothorax } \\
\hline No & $119(48.57)$ & $116(47.35)$ & Reference & ................. \\
\hline Yes & $2(25.00)$ & $5(62.50)$ & $4.80(0.45,51.24)$ & $>0.05$ \\
\hline \multicolumn{5}{|c|}{ Anastomosis leakage \& Fistula } \\
\hline No & $116(50.88)$ & $112(49.12)$ & Reference & ................. \\
\hline Yes & $5(35.71)$ & $9(64.29)$ & $1.70(0.30,9.40)$ & $>0.05$ \\
\hline \multicolumn{5}{|c|}{ Atrial fibrillation } \\
\hline No & $114(48.10)$ & $112(47.26)$ & Reference & .................. \\
\hline Yes & $7(43.75)$ & $9(56.25)$ & $0.90(0.24,3.26)$ & $>0.05$ \\
\hline \multicolumn{5}{|c|}{ Bleeding requiring second surgery } \\
\hline No & $119(50.00)$ & $119(50.00)$ & Reference & .................. \\
\hline Yes & $2(50.00)$ & $2(50.00)$ & $0.90(0.07,10.90)$ & $>0.05$ \\
\hline \multicolumn{5}{|c|}{ Hospital mortality } \\
\hline No & $116(48.33)$ & $114(47.50)$ & Reference & .................. \\
\hline Yes & $5(38.46)$ & $7(53.85)$ & $1.51(0.30,7.54)$ & $>0.05$ \\
\hline
\end{tabular}

*Adults Respiratory Distress Syndrome

The average days of ICU admission and intubation period were $4.70 \pm 8.41$ and $3.08 \pm 9.50$ in the TTE and $3.50 \pm 4.54$ and 1.76+_4.30 in THE methods respectively, which shows they were both significantly higher in the TTE Method(PValue $=0.0001$ ).

\section{Association between Complications and Mortality}

Table $\mathbf{5}$ shows that risk of mortality is directly related to ARDS, ventilator dependency and post-operative bleeding that requires re-operation. Risk of pneumonia, anastomosis leakage $\&$ fistula and chylothorax were not associated with mortality. 
Table 5: Adjusted odds ratios (OR) and corresponding 95\% confidence interval (Cl) for association between hospital mortality and different complications among patients who underwent esophagectomy during the years 2006 to 2012 in Cancer Institute of I.R Iran, Tehran, Iran

\begin{tabular}{|c|c|c|c|}
\hline & Hospital Mortality & & \\
\hline & $(\mathrm{Yes}(\%) / \mathrm{No}(\%))$ & Adjusted OR (95\% Cl) & P-Value \\
\hline \multicolumn{4}{|c|}{ Pneumonia } \\
\hline No & $8(3.36) / 230(96.64)$ & Reference & ................... \\
\hline Yes & $5(31.25) / 11(68.75)$ & $2.30(0.20,25.71)$ & $>0.05$ \\
\hline \multicolumn{4}{|c|}{ ARDS } \\
\hline No & $6(2.61) / 224(97.39)$ & Reference & ................. \\
\hline Yes & $7(29.17) / 17(70.83)$ & $15.38(2.203,107.30)$ & $<0.05$ \\
\hline \multicolumn{4}{|c|}{ Pulmonary embolism } \\
\hline No & $11(4.42) / 238(95.58)$ & Reference & ................... \\
\hline Yes & $2(40.00) / 3(60.00)$ & $5.91(0.24,143.71)$ & $>0.05$ \\
\hline \multicolumn{4}{|c|}{ Ventilator dependency (more than 48h) } \\
\hline No & $8(3.29) / 235(96.71)$ & Reference & ................ \\
\hline Yes & $5(45.45) / 6(54.55)$ & $42.60(3.24,558.52)$ & $<0.05$ \\
\hline \multicolumn{4}{|c|}{ Chylothorax } \\
\hline No & $11(4.47) / 235(95.53)$ & Reference & ................. \\
\hline Yes & $2(25.00) / 6(75.00)$ & $1.63(0.02,164.90)$ & $>0.05$ \\
\hline \multicolumn{4}{|c|}{ Anastomosis leakage $\&$ fistula } \\
\hline No & $11(4.62) / 227(95.38)$ & Reference & ................... \\
\hline Yes & $2(12.50) / 14(87.50)$ & $2.10(0.16,26.48)$ & $>0.05$ \\
\hline \multicolumn{4}{|c|}{ Bleeding requiring second surgery } \\
\hline No & $12(4.82) / 237(95.18)$ & Reference & ................. \\
\hline Yes & $1(20.00) / 4(80.00)$ & $24.12(1.05,549.40)$ & $<0.05$ \\
\hline \multicolumn{4}{|c|}{ Atrial fibrillation } \\
\hline No & $9(3.78) / 229(96.22)$ & Reference & ….............. \\
\hline Yes & $4(25.00) / 12(75.00)$ & $2.82(0.30,30.31)$ & $>0.05$ \\
\hline \multicolumn{4}{|c|}{ Arterial PH disorder * } \\
\hline No & $5(3.57) / 135(96.43)$ & Reference & ................ \\
\hline Yes & 8(7.02)/106 (92.98) & $0.32(0.05,2.00)$ & $>0.05$ \\
\hline
\end{tabular}

* two or more abnormal Arterial Blood Gas after surgery

\section{DISCUSSION}

Esophagectomy is the standard treatment for non-metastatic esophageal cancer. Despite improvements in surgery methods, appropriate patient selection and pre/post-operative management, esophagectomy is still associated with considerable risk of morbidity and mortality (4), since it is one of the most complex and major procedures of general surgery. This complexity is considered to be due to surgery in three fields (neck, abdomen, and thoracic cavity), mediastinal dissection and presence of a reconstructive organ in the mediastinum which causes dysfunction of respiratory muscles and respiratory problems $(9,11)$.

Multiple factors such as surgical method, patient age and medical comorbidity, may influence post-operative complications $(9,11)$.

Post-esophagectomy complications are divided into medical and surgical complication. Our findings showed that $24.02 \%(61 / 254)$ of patients experienced complications following esophagectomy.

\section{Medical Complications}

Many reports have indicated that pulmonary complications are the most common complication after esophagectomy and are one of the main causes of mortality $(4,7,9,11-14)$. Similarly, respiratory complications (including ARDS $9.45 \%$, pneumonia $6.30 \%$ and ventilator dependency $4.33 \%$ )were the most prevalent complication $(20.08 \%)$ in our study. Furthermore, in our study respiratory complications are significantly associated with increased mortality, except for pneumonia.

In a study by Avendano et al. (11) between 1994 and 2000, significant pulmonary complications were seen in 36.1\% of patients. The most common pulmonary complication was pneumonia, occurring in $32.8 \%$ of patients, $19.7 \%$ needed ventilation support for more than $48 \mathrm{~h}$, ARDS developed in $9.8 \%$ of cases, chylothorax was $8.2 \%$ and hospital mortality 
8.6\%. All the cases of in-hospital mortality had developed pneumonia. The mean ICU admission period was $6.1 \pm 11.1$ days and mean ventilation time $91.8 \pm 226.2 \mathrm{~h} \mathrm{(11)}$.

Mortality, complications, duration of ventilator support and admission period in the ICU were higher in this study compared to ours, which may be due to difference in the date of the two studies. Mortality of esophagectomy has decreased since the past decades(4) which may be due to increased experience of surgeons, improvements in patient selection, ICU care, and diagnostic and therapeutic facilities. In the study mentioned above, most cases of mortality were related to pneumonia, but in our study there was no significant association between pneumonia and mortality, this indicates that in case of early diagnosis and treatment with appropriate antibiotics, and proper ICU care, patient mortality can be decreased.

Also a recent study in Japan between 2005 and 2012 showed that overall respiratory complications were $17.7 \%$. Pneumonia ( $8.7 \%)$ and ventilator support more than $48 \mathrm{~h}(5.4 \%)$ were the main complications [12]. The results of this study, which was done at approximately the same period of our study, was relatively close to our findings.

\section{Medical Complications \\ Anastomosis leakage and fistula formation}

Anastomosis leakage is considered as one of the most important and serious surgical complications, that can result in mediastinal infection and sepsis. In our study, the rate of anastomosis leakage and fistula was $6.30 \%$, and it ranged between $3 \%-21.3 \%$ in other investigations $(4,7,15,16)$. We found no significant association between anastomosis leakage and mortality, that may be due to anastomosis being located in the neck in most surgeries, which has a lower risk of mediastinitis.

\section{Re-operation due to bleeding}

Re-operation due to bleeding was $1.97 \%$ in our study, in other studies it was reported ranging from $0.4 \%-7 \%(7,17$, 18). According to our findings, post-operative bleeding was significantly associated with mortality. Also, multiple studies have indicated peri-operative bleeding as a risk factor of mortality $(4,7,8)$.

\section{Risk factors}

Multiple investigations have been performed to determine the important risk factors that affect esophagectomy complications.

\section{Age}

In the present study, older age was associated with post-operative complications, this finding correlates with other studies $(6,14)$. However some authors reported that, patient's age at the time of surgery, had no impact on postoperative morbidity and mortality $(7,19)$. Furthermore, some investigations suggest that old age is not associated with bad outcomes, if the other comorbidities of patients are properly controlled $(20,21)$.

\section{History of cardio-pulmonary disease}

In the current study, history of cardio-pulmonary diseases significantly increased post-operative complications and mortality. Other studies reported similar findings $(7,8,10,22)$.

\section{Intra-operative blood transfusion}

In our study, intra-operative blood transfusion was associated with post-operative complications. Similarly, multiple investigations showed that intra-operative blood transfusion increased post-operative complications $(12,14-16,23)$. Various publications have shown that blood transfusion is a factor that increases mortality $(7,8,14$, 24), whereas our findings indicated that blood transfusion increases complications, but not mortality. Also, Nozoe $T$ et al reported that intra-operative blood transfusion was not indicative of the patient's prognosis (25).

\section{Surgical approach}

In the present study, pneumonia was significantly higher in the TTE method compared to the THE method, which is similar to other studies $(8,26)$.

There was no significant difference between the two groups regarding total complications, in-hospital mortality, ARDS, anastomosis leakage and fistula formation. These findings are consistent with the results of other studies (10, 2729). 
Multiple studies $(8,26,30-32)$ have shown that the TTE method is associated with more complications, and some (10, 27-29) have shown no significant difference between the two methods, which is similar to our study. Although, in a single study (33) the THE method was associated with more complications. This may be due to various factors, such as experience of the surgeons, the center in which the surgery is done, and bias in patient selection.

Therefore, for an accurate comparison between these two methods, a randomized clinical trial study is required.

\section{Neo-adjuvant therapy}

In the current study, there was no difference in total complications and mortality between the group who received neo-adjuvant treatment and the group who didn't. In a study in Norway, high dose chemo-radiation didn't affect pulmonary complications (34). Also, in a recent study, pre-operative radiotherapy didn't increase anastomotic complications in the post-operative period (35). Although, in a study in Japan, pre-operative definite chemo-radiotherapy was associated with increased respiratory complications (12).

\section{Mortality}

We found that the prevalence of in-hospital mortality was $5.12 \%$, which is consistent with K Ovrebo's findings (5.7\%)(29). In other publications, post-esophagectomy mortality rates varied between $(2.7-11 \%)(8,10,36-39)$.

In a comparison between the present study and a previous study (10) also done in Iran's cancer institute (1997-2006), in-hospital mortality had decreased in our study compared to the $11 \%$ reported before. It seems that gaining more experience by the surgeons, and improvements in ICU and peri-operative care, are effective in reducing mortality rate.

Our study revealed that History of cardio-pulmonary disease, ARDS, ventilator dependency and post-surgery bleeding were risk factors for in-hospital mortality.

The limitation of our research was the type of study, which was retrospective and so randomization of the data was not possible. For future investigations, a prospective randomized trial is recommended.

\section{CONCLUSION}

It is concluded that post esophagectomy complications are relatively common and are divided to surgical and medical. Surgical complications (such as bleeding, anastomosis leakage and fistula, chylothorax, ...) can be reduced by increasing the experience and skill of the surgical team. The most common medical complications are respiratory complications. Medical complications can be managed by proper patient selection, respiratory care before and after surgery, improving ICU care, and early diagnosis and treatment of complications. Although, in this study, no significant difference was observed between the two methods (TTE and THE) in terms of mortality, but in patients with associated respiratory disease, the THE method may be preferable.

\section{REFERENCES}

1. Zhang Y. Epidemiology of esophageal cancer. World journal of gastroenterology: WJG. 2013;19(34):5598. https://doi.org/10.3748/wjg.v19.i34.5598 PMid:24039351 PMCid:PMC3769895

2. Torre LA, Bray F, Siegel RL, Ferlay J, Lortet-Tieulent J, Jemal A. Global cancer statistics, 2012. CA: a cancer journal for clinicians. 2015;65(2):87-108. https://doi.org/10.3322/caac.21262

3. Oschner A, DeBakey M. Surgical aspects of carcinoma of the esophagus. J Thorac Surg. 1941;10:401-45.

4. Law S, Wong K-H, Kwok K-F, Chu K-M, Wong J. Predictive factors for postoperative pulmonary complications and mortality after esophagectomy for cancer. Annals of surgery. 2004;240(5):791. https://doi.org/10.1097/01.sla.0000143123.24556.1c PMid:15492560 PMCid:PMC1356484

5. Low DE, Alderson D, Cecconello I, Chang AC, Darling GE, D'Journo XB, et al. International consensus on standardization of data collection for complications associated with esophagectomy: Esophagectomy Complications Consensus Group (ECCG). Annals of surgery. 2015;262(2):286-94. https://doi.org/10.1097/SLA.0000000000001098 PMid:25607756

6. Togo S, Li J, Ligang L, Wei X, Tiechang P, Chen T, et al. Complications and mortality after esophagectomy for esophageal carcinoma: risk factor analysis in a series of 378 patients. Chir Thorac Cardio-Vasc. 2010;14:25-8.

7. Griffin SM, Shaw IH, Dresner SM. Early complications after Ivor Lewis subtotal esophagectomy with two-field lymphadenectomy: risk factors and management. Journal of the American College of Surgeons. 2002;194(3):28597. https://doi.org/10.1016/S1072-7515(01)01177-2 
8. Gockel I, Exner C, Junginger T. Morbidity and mortality after esophagectomy for esophageal carcinoma: a risk analysis. World journal of surgical oncology. 2005;3(1):37. https://doi.org/10.1186/1477-7819-3-40

9. Ferguson MK, Durkin AE. Preoperative prediction of the risk of pulmonary complications after esophagectomy for cancer. The Journal of thoracic and cardiovascular surgery. 2002;123(4):661-9. https://doi.org/10.1067/mtc.2002.120350

10. Mir MR, Rajabpour MV, Delarestaghi MM, Hadji M, Harirchi I, Mir P, et al. Short-and long-term survival of esophageal cancer patients treated at the Cancer Institute of Iran. Digestive surgery. 2013;30(4-6):331-6. https://doi.org/10.1159/000354854 PMid:24051550

11. Avendano CE, Flume PA, Silvestri GA, King LB, Reed CE. Pulmonary complications after esophagectomy. The Annals of thoracic surgery. 2002;73(3):922-6. https://doi.org/10.1016/S0003-4975(01)03584-6

12. Yoshida $N$, Watanabe $M$, Baba $Y$, Iwagami $S$, Ishimoto $T$, Iwatsuki $M$, et al. Risk factors for pulmonary complications after esophagectomy for esophageal cancer. Surgery today. 2014;44(3):526-32. https://doi.org/10.1007/s00595-013-0577-6 PMid:23584275

13. Yannopoulos $P$, Theodoridis $P$, Manes K. Esophagectomy without thoracotomy: 25 years of experience over 750 patients. Langenbeck's archives of surgery. 2009;394(4):611-6. https://doi.org/10.1007/s00423-009-0488-6 PMid:19350267 PMCid:PMC2687514

14. Bailey SH, Bull DA, Harpole DH, Rentz JJ, Neumayer LA, Pappas TN, et al. Outcomes after esophagectomy: a tenyear prospective cohort. The Annals of thoracic surgery. 2003;75(1):217-22. https://doi.org/10.1016/S00034975(02)04368-0

15. Dewar L, Gelfand G, Finley RJ, Evans K, Inculet R, Nelems B. Factors affecting cervical anastomotic leak and stricture formation following esophagogastrectomy and gastric tube interposition. The American journal of surgery. 1992;163(5):484-9. https://doi.org/10.1016/0002-9610(92)90393-6

16. Tabatabai A, Hashemi M, Mohajeri G, Ahmadinejad M, Khan IA, Haghdani S. Incidence and risk factors predisposing anastomotic leak after transhiatal esophagectomy. Annals of thoracic medicine. 2009;4(4):197. https://doi.org/10.4103/1817-1737.56012 PMid:19881165 PMCid:PMC2801044

17. Law SY, Fok M, Wong J. Risk analysis in resection of squamous cell carcinoma of the esophagus. World journal of surgery. 1994;18(3):339-46. https://doi.org/10.1007/BF00316812 PMid:8091773

18. Schieman C, Wigle DA, Deschamps C, Nichols lii F, Cassivi S, Shen K, et al. Patterns of operative mortality following esophagectomy. Diseases of the Esophagus. 2012;25(7):645-51. https://doi.org/10.1111/j.14422050.2011.01304.x PMid:22243561

19. Mirza A, Pritchard S, Welch I. Is surgery in the elderly for oesophageal cancer justifiable? Results from a single centre. ISRN surgery. 2013;2013.

20. McLoughlin JM, Lewis JM, Meredith KL. The impact of age on morbidity and mortality following esophagectomy for esophageal cancer. Cancer Control. 2013;20(2):144-50. https://doi.org/10.1177/107327481302000208 PMid:23571705

21. Pultrum B, Bosch $D$, Nijsten $M$, Rodgers $M$, Groen $H$, Slaets J, et al. Extended esophagectomy in elderly patients with esophageal cancer: minor effect of age alone in determining the postoperative course and survival. Annals of surgical oncology. 2010;17(6):1572-80. https://doi.org/10.1245/s10434-010-0966-7 PMid:20180031 PMCid:PMC2868167

22. Paul DJ, Jamieson GG, Watson DI, Devitt PG, Game PA. Perioperative risk analysis for acute respiratory distress syndrome after elective oesophagectomy. ANZ journal of surgery. 2011;81(10):700-6. https://doi.org/10.1111/j.1445-2197.2010.05598.x PMid:22295310

23. Langley SM, Alexiou C, Bailey DH, Weeden DF. The influence of perioperative blood transfusion on survival after esophageal resection for carcinoma. The Annals of thoracic surgery. 2002;73(6):1704-9. https://doi.org/10.1016/S0003-4975(02)03508-7

24. Bernard AC, Davenport DL, Chang PK, Vaughan TB, Zwischenberger JB. Intraoperative transfusion of $1 \mathrm{U}$ to $2 \mathrm{U}$ packed red blood cells is associated with increased 30-day mortality, surgical-site infection, pneumonia, and sepsis in general surgery patients. Journal of the American College of Surgeons. 2009;208(5):931-7. e2.

25. Nozoe T, Miyazaki M, Saeki H, Ohga T, Sugimachi K. Significance of allogenic blood transfusion on decreased survival in patients with esophageal carcinoma. Cancer. 2001;92(7):1913-8. https://doi.org/10.1002/10970142(20011001)92:7<1913::AID-CNCR1709>3.0.CO;2-8 
26. Colvin H, Dunning J, Khan OA. Transthoracic versus transhiatal esophagectomy for distal esophageal cancer: which is superior? Interactive cardiovascular and thoracic surgery. 2011;12(2):265-9. https://doi.org/10.1510/icvts.2010.252148 PMid:21051381

27. Connors RC, Reuben BC, Neumayer LA, Bull DA. Comparing outcomes after transthoracic and transhiatal esophagectomy: a 5-year prospective cohort of 17,395 patients. Journal of the American College of Surgeons. 2007;205(6):735-40. https://doi.org/10.1016/j.jamcollsurg.2007.07.001 PMid:18035255

28. Rentz J, Bull D, Harpole D, Bailey S, Neumayer L, Pappas T, et al. Transthoracic versus transhiatal esophagectomy: a prospective study of 945 patients. The Journal of thoracic and cardiovascular surgery. 2003;125(5):1114-20. https://doi.org/10.1067/mtc.2003.315 PMid:12771885

29. Ovrebo KK, Lie SA, Laerum OD, Svanes K, Viste A. Long-term survival from adenocarcinoma of the esophagus after transthoracic and transhiatal esophagectomy. World journal of surgical oncology. 2012;10(1):130. https://doi.org/10.1186/1477-7819-10-130 PMid:22747995 PMCid:PMC3476969

30. Hulscher JB, Tijssen JG, Obertop H, van Lanschot JJB. Transthoracic versus transhiatal resection for carcinoma of the esophagus: a meta-analysis. The Annals of thoracic surgery. 2001;72(1):306-13. https://doi.org/10.1016/S0003-4975(00)02570-4

31. Boshier PR, Anderson O, Hanna GB. Transthoracic versus transhiatal esophagectomy for the treatment of esophagogastric cancer: a meta-analysis. Annals of surgery. 2011;254(6):894-906. https://doi.org/10.1097/SLA.0b013e3182263781 PMid:21785341

32. Donohoe CL, O'Farrell NJ, Ravi N, Reynolds JV. Evidence-based selective application of transhiatal esophagectomy in a high-volume esophageal center. World journal of surgery. 2012;36(1):98-103. https://doi.org/10.1007/s00268-011-1307-0 PMid:21979584

33. Kawoosa NU, Dar AM, Sharma ML, Ahangar AG, Lone GN, Bhat MA, et al. Transthoracic versus transhiatal esophagectomy for esophageal carcinoma: experience from a single tertiary care institution. World journal of surgery. 2011;35(6):1296-302. https://doi.org/10.1007/s00268-011-1020-z PMid:21384241

34. Hurmuzlu M, Øvrebø K, Wentzel-Larsen T, Muren LP, Viste A, Smaaland R. High-dose preoperative chemoradiotherapy in esophageal cancer patients does not increase postoperative pulmonary complications: Correlation with dose-volume histogram parameters. Radiotherapy and Oncology. 2010;97(1):60-4. https://doi.org/10.1016/j.radonc.2010.06.008 PMid:20708284

35. Koëter M, van der Sangen MJ, Hurkmans CW, Luyer MD, Rutten HJ, Nieuwenhuijzen GA. Radiation dose does not influence anastomotic complications in patients with esophageal cancer treated with neoadjuvant chemoradiation and transhiatal esophagectomy. Radiation oncology. 2015;10(1):59. https://doi.org/10.1186/s13014-015-0361-4 PMid:25884226 PMCid:PMC4369843

36. Markar S, Karthikesalingam A, Thrumurthy S, Ho A, Muallem G, Low D. Systematic review and pooled analysis assessing the association between elderly age and outcome following surgical resection of esophageal malignancy. Diseases of the Esophagus. 2013;26(3):250-62. https://doi.org/10.1111/j.1442-2050.2012.01353.x PMid:22591068

37. Berry MF, Atkins BZ, Tong BC, Harpole DH, D'amico TA, Onaitis MW. A comprehensive evaluation for aspiration after esophagectomy reduces the incidence of postoperative pneumonia. The Journal of thoracic and cardiovascular surgery. 2010;140(6):1266-71. https://doi.org/10.1016/j.jtcvs.2010.08.038 PMid:20884018 PMCid:PMC3147296

38. Homesh N, Alsabahi A, Al-Agmar M, Alwashaly A, Valenzuela R, Alhadid M, et al. Transhiatal versus transthoracic resection for oesophageal carcinoma in Yemen. Singapore medical journal. 2006;47(1):54-9. PMid:16397722

39. Wright CD, Kucharczuk JC, O'brien SM, Grab JD, Allen MS. Predictors of major morbidity and mortality after esophagectomy for esophageal cancer: a Society of Thoracic Surgeons General Thoracic Surgery Database risk adjustment model. The Journal of thoracic and cardiovascular surgery. 2009;137(3):587-96. https://doi.org/10.1016/j.jtcvs.2008.11.042 PMid:19258071

$$
\diamond \diamond \diamond \diamond \diamond \diamond \diamond
$$

http://www.ejgm.co.uk 